\title{
Investor Sentiment, Human Capital and Fama French Factors: Measurement and Performance in the Malaysian Market
}

\author{
(Sentimen Pelabur, Modal Insan dan Faktor-Faktor Fama French: Pengukuran dan Prestasi \\ di Pasaran Malaysia) \\ Chandana Gunathilaka \\ (Faculty of Management Studies and Commerce, University of Sri Jayewardenepura) \\ Mohamad Jais \\ (Faculty of Economics and Business, University Malaysia Sarawak)
}

\begin{abstract}
This paper examines pricing implications of investors' behavioral biasness in the Malaysian equity market. By using monthly data from January 2000, through January 2014, we explore the impact of investor sentiment, human capital, and Fama-French risk factors in multiple factor asset pricing models. A unique seven-variable composite index is used for the measurement of investor sentiment. Results indicate that sentiment is a priced risk, and display the ability to capture returns unexplained by SMB (Small minus Big) and HML (High minus Low) factors. Evidence suggests that sentiment is a source of systemic risk, and effectively explains returns of stocks with opaque characteristics. Modeling aggregate labor income produces insignificant results, suggesting that there are no returns for human capital in the Malaysian equity market. The Fama and French three factor model together with investor sentiment risk achieves a substantial pricing efficiency.
\end{abstract}

Keywords: Investor sentiment; human capital; returns; Malaysia.

ABSTRAK

Kajian ini menyelidik tentang implikasi gelagat pelabur yang bias di pasaran Malaysia. Dengan menggunakan data bulanan dari bulan Januari 2000 hingga bulan Januari 2014, kami mengkaji kesan sentimen pelabur, modal insan dan faktor risiko Fama-French dalam model perletakan harga aset pelbagai faktor. Tujuh pembolehubah yang unik digunakan untuk mengukur sentimen pelabur. Hasil kajian menunjukkan bahawa sentimen adalah risiko harga, dan memaparkan keupayaan untuk mengambil kira pulangan yang tidak dapat dijelaskan oleh factor SMB (Kecil tolak Besar) dan faktor HML (Tinggi tolak Rendah). Bukti kajian menunjukkan bahawa sentimen adalah sumber risiko yang sistematik, dan dengan jelas menerangkan pulangan saham yang mempunyai ciri-ciri legap. Hasil kajian juga menunjukkan model pendapatan tenaga kerja adalah tidak signifikan dan keputusan ini menggambarkan bahawa tidak ada pulangan untuk modal insan di pasaran Malaysia. Model tiga faktor Fama-French bersama dengan risiko sentimen pelabur mencapai kecekapan harga yang besar.

Kata kunci: Sentimen pelabur; modal insan; pulangan; Malaysia.

\section{INTRODUCTION}

Market rationality is the base for predictions of mainstream asset pricing models like the capital asset pricing model (CAPM) (Sharpe 1964; Lintner 1965). But the facts do not support the CAPM (Dempsey 2013). Alternatively, behavioural models recognize irrationality of the market participants to be a priced risk. Both the failure of traditional asset pricing theory and the role of investor sentiment are no more news to finance practitioners. Nevertheless, asset pricing practice shows an affinity with the use of traditional pricing models, especially in emerging markets. Valuation of assets has been a challenge in Malaysia (Foong \& Goh 2010) and there is no clear practical model. While application of less appropriate models often creates under/over market valuations at the investors' cost, it also subsidises behavioural biasness in the market.
Evidence confirm behavioral biasness in the Malaysian stock market, for instance the herding effect (Jarita \& Salina 2009; Chiang \& Zheng 2010), thus making demand shifts influenced by speculations. This may generate a systematic sentiment risk. However, sentiment based asset pricing models are still in the exploratory stage (Yang \& Li 2013) and the literature accepts that there are no definitive sentiment measures (Mahakud \& Dash 2012). Impracticability of available behavioural models may also result in limited application. On the one hand, sentiment proxies used in developed markets are inconvenient in emerging markets due to the limited operational activity and information asymmetry. For instance, sentiment proxies derived from a derivatives market serve well in developed markets due to market size and trading frequency. On the other hand, practitioner's reliability depends on strong empirical evidence. Inadequacy of empirical support creates a reasonable reservation on 
model applications. Research on investor sentiment has a history of at least seven decades (Stambaugh, Yu \& Yuan 2012) even though traditional asset pricing models completely ignore the impact. Baker and Wurgler (2006), among others, provide influencing evidence that the investors' sentiment is a priced risk. One of the deficiencies in this area of behavioural research is that the expectation of a concrete and rational measurement from irrational human decisions. Many recent studies demonstrate different methods of sentiment measures, for instance, Feldman (2010) argues on loss aversion, and proposes a 'perceived loss index' which outperforms other sentiment measures. Stambaugh et al. (2012) use the index proposed by Baker and Wurgler (2007). Furthermore, Da, Engelberg and Gao (2014) find that investor sentiment is indicated by internet search behaviour of households. It suggests that the models need revisiting, especially in markets with different operational and ownership settings. Evidence put forward by these studies pose a serious challenge to the Efficient Market Hypothesis, even though Fama (1998) interprets them as chance results.

Retail investors' sentiment may perhaps show a link to current and expected wealth. In particular, an investor may be influenced by the present wealth of future labor income. Jagannathan and Wang (1996) find that the growth rate in aggregate labor income is a priced risk factor. This suggests that the labor market influences the behavior of the capital market, and thus human capital (HC) plays a role in pricing. Betermier et al. (2012) find that households do adjust their portfolio holdings when switching jobs. If the sentiment is assumed to be independent of the impact of hedging against human capital risk, HC may be an important risk factor in an economy like Malaysia's where the labor income share is substantial. Malaysia's labor income, as a percent of GDP, has been growing (reported as $2005-37 \% ; 2013-42 \%$ ) during the past decade' ${ }^{1}$. Thus, modeling aggregate labor income to account for the missing wealth component in pricing may be important. This is consistent with Campbell (1996)'s innovations in state variables that help to forecast future labor income.

In the present context, this paper has been designed to serve two purposes; (1) Suggesting a sentiment index using Malaysian aggregate market proxies, (2) Examining the pricing implications of sentiment risk after controlling the influence of human capital and Fama-French (FF) risk factors. We inspect the efficiency of these risk factors in a multifactor arbitrage pricing theory (APT) framework. The paper contributes to the existing literature in several aspects; first, it presents an emerging market composite sentiment index with reference to the Malaysian stock market. Our measure of market wide investor sentiment consists of seven proxies including a new proxy which has not been used in prior literature. Second, it documents the impact of the human capital risk factor in asset pricing, to the best of the authors knowledge, it makes a first attempt to test the impact of human capital risk on the Malaysian equity returns in cross section. Third, we present evidence of causality between sentiment measured by the seven variable index proposed in this paper and the consumer sentiment index published by the Malaysian Institute of Economic Research (MIER). Finally, we investigate pricing implications of sentiment and human capital risks in presence of Fama and French (1993) risk factors using listed firms in the Malaysian stock market. Therefore, this paper contributes to the limited literature on measurement and role of behavioral factors in the Malaysian stock market.

In the rest of the paper, we review the related literature in section 2. Section 3 covers a discussion of the proposed sentiment index, and the method of building other risk factors together with an empirical model. We describe test results and our evaluations in section 4 , followed by managerial implications and consequent conclusions.

\section{LITERATURE REVIEW}

Fama and French (1993) explain the cross-sectional variation in expected returns with three factors, market risk premium, Small minus Big (SMB, the size effect; Banz 1981) and High minus Low book-to-market (HML, the value effect, Rosenberg, Reid \& Lanstein 1985). Fama-French (FF) model received substantial support subsequently. However, Chen and Zhang (2010) argue that there are reasons where the FF model fails. Positive relations of average returns with short-term prior returns and earnings surprises, negative relations of average returns with financial distress, net stock issues, and asset growth are their examples. The other significant risk factors include the effect of liquidity (Amihud \& Mendelson 1986; Lam \& Tam 2011), momentum trading effect (Jegadeesh \& Titman 1993; Carhart 1997) and behavioral factors including investor sentiment and human capital (Campbell 1996).

Campbell (1996) uses growth in aggregate labor income to proxy the human capital impact and document that human capital is a priced risk factor. Campbell and Korniotis (2008) propose a human capital asset pricing model (HCAPM) using income growth of households. They find substantial returns to human capital, and significantly, estimation errors of asset pricing models could be overcome by including household-human capital. Yuan (2012) models aggregate labor income, employment hours, unemployment, and labor participation with the FF model. It shows that unemployment rate plays a critical role in explaining returns. Evidence of hedging in stock markets against human capital risk (Betermier et al. 2012) is imperative for pricing in an economy where job switching cost is low. It becomes significant when a market is widely held, as the retail investors match their job risk (Betermier et al. 2012) with the risk of the portfolio held. They construct a measure of wage volatility and test with risky portfolio switcher. However, an individual measure may not produce better results in the Malaysian market, as the ownership of most Malaysian companies are commonly concentrated among the State, families 
or individuals (Amran \& Ahmad 2013). In a different approach, Kim, Kim and Shin (2012) use aggregate labor income growth to proxy human capital risk and demonstrate that there are returns for human capital. Yuan (2012) uses aggregate labor income in modeling human capital to include both marketed and non-marketed benefits. Hence, we confine ourselves to construct a risk factor to the effect of hedging against labor income growth, using aggregate data.

There has been a growing interest in studies in investor psychology as a potential explanation for stock price movements (Bandopadhyaya \& Jones 2006). Investors do not believe themselves during periods of market distress, instead they follow the market consensus (Christie \& Huang 1995). This forms herding in the market, and sentiment may play a significant role in identifying subsequent herding (Liao, Huang \& Yu 2011). Liao et al. (2011) observe that mutual fund herding follows market sentiment, especially on the sell-side. Fong and Toh (2014) show that investors' desire for stocks with lotterylike payoff is strongly dependent on investor sentiment. The behavioral biasness, whether cognitive, affective or both, therefore result in speculations, and limits arbitrage opportunities for rational investors. Hence, the literature argues that the sentiment is a systemic risk (Changsheng \& Yongfeng 2012) which epitomizes many psychological factors, behavioral biases in markets.

The literature shows success in application of both direct and indirect methods in sentiment quantification. Time series survey based indices such as the index of the American Association of Individual Investors (Brown \& Cilff 2004; Liu 2015) capture the biases in investor psychology directly. This 'bottom-up' approach (Baker \& Wurgler 2007) has the limitation in that it is challenging to determine market-wide sentiment using a few of the hypothesised psychological biases. Instead, the 'top-down' approach (Baker \& Wurgler 2007) uses market-wide implicit proxies to trace the sentiment and its impact on cross sectional returns. Baker and Wurgler (2007) obtain principal components of six sentiment proxies $^{2}$; TURN, DivP, CEFD, NIPO, RIPO, and EITI. Huang, Jiang and Zhou (2013) argue that the sentiment index of Baker and Wurgler (2007) underestimates predictive power due to application of the principal component approach. They propose an index using partial least squares instead. Alternatively, Da et al. (2014) show that an index of internet search behaviour of households can directly portray investor sentiment. They aggregate the volume of internet search queries such as 'recession' and 'bankruptcy.' Nevertheless, the search information often contributes to an individual's rational behavior, moreover, 'searching' affects more than indicating the investor's sentiment.

Some of the proxies used in these studies have limited application in emerging markets. Other than the common problem of information asymmetry, limited market activity and relatively less trading frequency are constraints in emerging markets. For instance, the Malaysian market had one closed-end fund during the sample period, resulting in limited market activity relative to developed markets. It corresponds with less market participation and consequently an indicator derived from such an activity would not serve well. Jun, Marathe and Shawky (2003) find positively correlated stock returns and Turnover Ratio (TR) in emerging markets. TR is used to capture liquidity shifts of the market and it is important applying a liquidity indicator since emerging markets are relatively illiquid. Other proxies used in the literature include, change in margin financing and put-call ratio (Brown \& Cliff 2004), buy and sell imbalance ratio (Kumar \& Lee 2006), share turnover velocity (Mahakud \& Dash 2012), net cash flows to equity funds (Randall, Suk \& Tully 2003), institutional churn (Chae \& Yang 2008) and number of new stock accounts (Changsheng \& Yongfeng 2012). We make use of these proxies, which we observe appropriate to the Malaysian market, in our effort of concocting a better pricing model.

\section{METHODOLOGY}

We apply an indirect method in measuring market wide investor sentiment (Baker \& Wurgler 2006, 2007), making use of DataStream, Bursa Malaysia and statistics of government authorities' data sources. Avoiding the impact of financial crisis reported in 1997, we sampled monthly returns from January 2000. The sampling period ends by January 2014 covering a period of 14 years. We use monthly value-weighted market returns using the Kuala Lumpur Composite Index and one-month Treasury bill yield (serves proxy for risk free rate). The first sentiment proxy is Advance-Decline Ratio (ADR) (Brown \& Cliff 2004; Finter, Niessen \& Ruenzi 2011) which is defined as the ratio of the number of advancing (market price) to declining stocks during a particular month. Second, we use turnover ratio (TR) (Jun et al. 2003) defined as the ratio between the values of shares traded and market capitalization. The third proxy is dividend premium (DivP) (Baker \& Wurgler 2007) which is the log difference of the average market-to-book ratios of dividend payer and non-payer stocks. Based on the argument that people seek dividend payers when the market is expected to be bearish, DivP is expected to show a negative relationship with the sentiment (Baker \& Wurgler 2007; Finter et al. 2011). We also use 'number of initial public offers' (NIPO) and initial day returns of IPO (RIPO) (Baker \& Wurgler 2007), these proxies have the ability to indicate sentiment as the IPO market behaviour is sensitive to ongoing capital market conditions. Our sixth proxy is the monthly percent change in margin finance position (CMF) (Brown \& Cliff 2004; Mahakud \& Dash 2012) as investors' borrowing level indicates the market conditions of bearish or bullish. The last proxy, the new proxy we use, is the monthly percent change in open interest (COI) from the equity derivatives market. Bessembinder and Seguin (1993) use open interest as a proxy for market depth. Open interest, open 
contracts on securities at the end of a period, is used to identify perceived trends in futures and options markets. The information role of open interest and its relationship with price changes have seen attractive to scholars (Wang \& Yu 2014). Open interest is used to confirm trends and trend reversals in the market. A rise in open interest represents a condition of new money coming to the market, consequently a bullish market is expected, thus it is hypothesized that this new indicator would show a positive relationship with the market bullishness.

\section{SENTIMENT INDEX}

Following Baker and Wurgler (2007) we obtain the irrational component of investor sentiment in an orthogonalising process of sentiment proxies (SP). For this purpose, five economic fundamentals variables are used. The first four of these have been applied in prior studies; they are growth in industrial production, exchange rate, change in consumer price index and the term spread (Finter et al. 2011; Mahakud \& Dash 2012). Additionally, motivated by the evidence of Campelo et al. (2013) who find that the composite index helps predict turning points in the business cycle, we use the coincident composite index (CCI) to account for changes in the business cycle.
CCI, which measures current economic activity ${ }^{3}$, and brings vital information for investment decision making. The orthogonalising econometric model would be confined to the model 1 below.

$$
S P_{j t}=\alpha_{j}+\sum_{k=1}^{l=5} \beta_{j} E F_{k t}+e_{t}
$$

Where, $S P_{j t}$ is the $j^{\text {th }}$ sentiment proxy at time $t, E F_{k t}$ is the $k^{\text {th }}$ Economic Fundamental variable at time $t$. Term $\alpha_{j}$ is the constant of the $j^{\text {th }}$ proxy with respect to $l$ number of $E F$ factors, limited to five in this study. Estimated $\widetilde{S P}$ represents the rational component of the sentiment and the residual $\left(e=S P_{j t}-\widetilde{S P}\right)$, which is orthogonal $\left(S P^{\perp}\right)$ to the original proxy, reflects the irrational component of sentiment. Table 1 and 2 reports summary statistics and correlation coefficients of pre and post orthogonal proxies. Five pre-orthogonal proxies show significant-weak correlations (Table 2) with KLCI, and four of these become insignificant in a post-orthogonal set. Post orthogonal COI is weakly-correlated with three other proxies. This suggests that the new indicator and orthogonalising procedure are more powerful, in that it eliminates common sentiment component which is, arguably, based on rationality and narrows down the variation of the proxy. The significantweak correlations between ADR, RIPO and TR are apparent as they share common information.

TABLE 1. Summary statistics of proxies

\begin{tabular}{|c|c|c|c|c|c|c|c|c|}
\hline & Mean & Std.D & Min & Max & Mean & Std.D & Min & $\operatorname{Max}$ \\
\hline & \multicolumn{4}{|c|}{ Before orthoganalising } & \multicolumn{4}{|c|}{ Orthogonalised variables } \\
\hline ADR & 1.406 & 1.756 & 0.043 & 12.088 & 0.000 & 1.718 & -1.867 & 10.122 \\
\hline TR & 0.026 & 0.010 & 0.009 & 0.064 & 0.000 & 0.009 & -0.015 & 0.040 \\
\hline DivP & -0.631 & 0.498 & -1.986 & 0.754 & 0.000 & 0.447 & -1.367 & 1.120 \\
\hline NIPO & 3.216 & 3.267 & 0.000 & 16.000 & 0.000 & 2.940 & -4.890 & 11.631 \\
\hline RIPO & 0.049 & 0.234 & -0.793 & 1.000 & 0.000 & 0.221 & -0.745 & 0.959 \\
\hline $\mathrm{CMF}$ & 1.198 & 6.282 & -39.048 & 63.018 & 0.000 & 6.261 & -40.359 & 61.420 \\
\hline $\mathrm{COI}$ & 3.260 & 19.550 & -44.540 & 105.110 & 0.000 & 0.194 & -0.495 & 0.998 \\
\hline
\end{tabular}

This table reports summary statistics of sentiment proxies, pre and post orthogonal. The proxies are; Advance decline ratio (ADR), Turnover ratio (TR), dividend premium (DivP), Number of IPO (NIPO), Initial returns of IPO (RIPO), Change in margin finance (CMF), and Change in open interest (COI).

The common component in the variations of SP $\perp$ are then isolated using Principal Components Analysis (PCA) (Baker \& Wurgler 2006; Mahakud \& Dash 2012). PCA would eliminate idiosyncratic and non-sentiment related remained component even after macro variables adjustments (Finter et al. 2011). We obtained six principal components which are calculated from the correlation matrix. Presented in table 3 are the first four of them. Analyses reveal that the hypothesized relationships are achieved within the first component. Three proxies become negative while dividend premium become positive in the second component. Changsheng and Yongfeng (2012) use an average of the first and second components giving weights to Eigen values of the two. However, some of their proxies show an inverse relationship in the second component. Hence, we are restricted to the selection of first principal component with a cumulative proportion of 0.238 . Finally, the sentiment index used in this paper is the first principal component of the orthogonalized proxies, $\mathrm{SP} \perp$. Hence, the final sentiment index is formed as given in equation 2 below.

$$
\begin{aligned}
& \mathrm{IS}=0.499 \mathrm{ADR}+0.478 \mathrm{TURN}-0.265 \mathrm{DivP}+0.254 \mathrm{NIPO} \\
& +0.374 \mathrm{RIPO}+0.143 \mathrm{CMF}+0.478 \mathrm{COI}
\end{aligned}
$$

In view of the evidence that the consumer confidence is an alternative to investor sentiment (Lemmon \& 
TABLE 2. Correlation matrix

\begin{tabular}{|c|c|c|c|c|c|c|c|c|}
\hline & KLCI & ADR & $\mathrm{TR}$ & DivP & IPO & RIPO & $\mathrm{CMF}$ & $\mathrm{COI}$ \\
\hline \multicolumn{9}{|c|}{ Before orthoganalising } \\
\hline ADR & 0.015 & 1 & & & & & & \\
\hline TR & $0.300 *$ & $0.198 *$ & 1 & & & & & \\
\hline DivP & $-0.216^{*}$ & -0.103 & -0.085 & 1 & & & & \\
\hline NIPO & $-0.288 *$ & -0.001 & 0.037 & -0.010 & 1 & & & \\
\hline RIPO & $0.269 *$ & 0.107 & $0.329 *$ & $-0.180 *$ & -0.021 & 1 & & \\
\hline $\mathrm{CMF}$ & 0.099 & 0.000 & $0.215^{*}$ & 0.012 & -0.106 & 0.040 & 1 & \\
\hline $\mathrm{COI}$ & $-0.032 *$ & 0.264 & 0.100 & -0.117 & 0.218 & 0.071 & 0.051 & 1 \\
\hline \multicolumn{9}{|c|}{ Orthogonalised Variables } \\
\hline ADR & 0.042 & 1 & & & & & & \\
\hline $\mathrm{TR}$ & 0.060 & $0.237 *$ & 1 & & & & & \\
\hline DivP & 0.054 & -0.132 & 0.017 & 1 & & & & \\
\hline NIPO & 0.026 & 0.023 & 0.094 & -0.101 & 1 & & & \\
\hline RIPO & 0.063 & 0.127 & $0.260 *$ & -0.076 & 0.001 & 1 & & \\
\hline $\mathrm{CMF}$ & 0.034 & 0.003 & $0.204 *$ & 0.044 & -0.102 & 0.021 & 1 & \\
\hline $\mathrm{COI}$ & $0.016^{*}$ & $0.271 *$ & 0.113 & $-0.148^{*}$ & $0.207 *$ & 0.079 & 0.053 & 1 \\
\hline
\end{tabular}

This table reports correlation coefficients of pre and post orthogonal proxies and the Kuala Lumpur Composite Index (KLCI), with significance at $* 1 \%$ level. The proxies are; Advance decline ratio (ADR), Turnover ratio (TR), dividend premium (DivP), Number of IPO (NIPO), Initial returns of IPO (RIPO), Change in margin finance (CMF), and Change in open interest (COI).

TABLE 3. Results of PCA

\begin{tabular}{|c|c|c|c|c|}
\hline & Component 1 & Component 2 & Component 3 & Component 4 \\
\hline$A D R^{\perp}$ & 0.499 & -0.028 & -0.141 & -0.322 \\
\hline$T R \perp$ & 0.478 & 0.414 & 0.069 & 0.300 \\
\hline $\operatorname{Div} P \perp$ & -0.265 & 0.413 & 0.314 & 0.434 \\
\hline$N I P O \perp$ & 0.254 & -0.460 & 0.433 & 0.569 \\
\hline 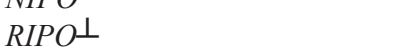 & 0.374 & 0.245 & -0.584 & 0.361 \\
\hline$C M F^{\perp}$ & 0.143 & 0.559 & 0.486 & -0.349 \\
\hline$C O I^{\perp}$ & 0.478 & -0.271 & 0.335 & -0.205 \\
\hline Eigen Pre- Orthogonal proxies & 1.566 & 1.164 & 1.124 & 0.933 \\
\hline Proportion & 0.224 & 0.166 & 0.161 & 0.133 \\
\hline Cumulative Proportion & 0.224 & 0.390 & 0.551 & 0.684 \\
\hline Eigen Orthogonalized proxies & 1.672 & 1.253 & 1.125 & 0.951 \\
\hline Proportion & 0.238 & 0.172 & 0.158 & 0.132 \\
\hline Cumulative Proportion & 0.238 & 0.365 & 0.503 & 0.625 \\
\hline
\end{tabular}

This table reports principal components of post-orthogonal proxies, Advance decline ratio (ADR), Turnover ratio (TR), dividend premium (DivP), Number of IPO (NIPO), Initial returns of IPO (RIPO), Change in margin finance (CMF), and Change in open interest (COI), and their respective Eigen values.

Portniaguina 2006), we compare the index devised above with the behavior of Business Conditions Index (BCI) and Consumer Sentiment Index (CSI) of the Malaysian Institute of Economic Research (Figure 1). Augmented Dickey Fuller unit root test (Table 4) explains that the CSI (at 5\% significance level) and IS (at 1\% significance level) are stationery. Hence, we use the pairwise granger causality test ${ }^{4}$, and statistics in table 4 indicate a unidirectional Granger causality of IS $_{\mathrm{t}-9}$ to $\mathrm{CSI}_{\mathrm{t}}$. This suggests that investor sentiment is an early indicator of CSI, hence is a reliable sentiment index in the Malaysian market. However, the study finds no causation between is and BCI.

\section{RISK FACTORS AND EMPIRICAL MODEL}

We follow studies of Fama and French (1993), Carhart (1997) and Kim et al. (2012) in constructing SMB and HML risk factors. In this process, size bisects at 50 percent break point and BM trisects at $30^{\text {th }}$ and $70^{\text {th }}$ percentiles. SMB is the return for the small stock portfolio in excess of the big. It is the simple average of value weighted returns of three small stock portfolios (i.e. Small-High BM, Small-Middle BM, and Small-Low BM) minus three big stock portfolios (i.e. Big-High BM, Big-Middle BM, and Big-Low BM). HML is estimated in a similar process to SMB. HML is the return 


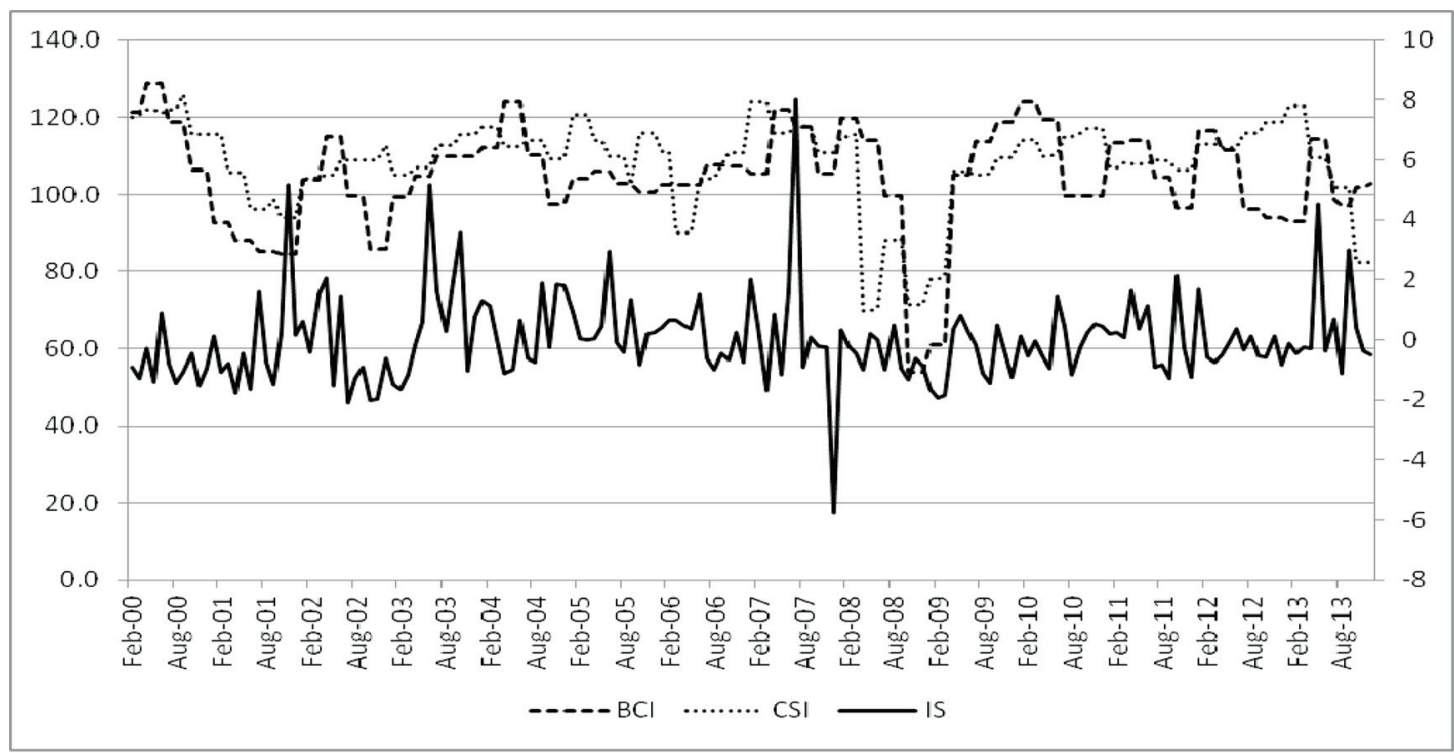

FIGURE 1. Depiction of the behavior of the Business Confidence Index, Consumer Sentiment Index (Left Y-axis) and Investor Sentiment Index (Right Y-axis); the figure is in a two scale format

TABLE 4. Granger Causality

\begin{tabular}{cccc}
\hline Regression & ADF Test (level) t-stat & F-Stat. (Prob.) & Implication \\
\hline IS on CSI & $-3.237^{* *}$ & $3.3914^{*}(0.000)$ & IS causing CSI (Significant) \\
CSI on IS & $-11.415^{*}$ & $0.5039(0.8697)$ & CSI causing IS (Insignificant) \\
\hline
\end{tabular}

This table reports pairwise Granger Causality test statistics between the Consumer sentiment index and the Investor sentiment index, with significance

$*$ at $1 \%$ and $* *$ at $5 \%$ level. No. of Lags starts from 9 . ADF test uses time series at level, a constant and lags selected on minimum of AIC.

for the high BM stock portfolio over the low, it is the simple average of value weighted returns of two high BM stock portfolios (i.e. High-Small, High-Big) minus two low BM stock portfolios (i.e. Low-Small, Low-Big).

The Human capital (HC) risk factor estimation follows the method of Kim et al. (2012). First, we run a regression ${ }^{5}$ on stock returns (dependant variable) and labor income growth $\left(\mathrm{L}_{\mathrm{t}}\right)$ in a rolling window of 36 month time series, and estimate the stock's sensitivity to labor income growth, $\beta L$. Then stocks are ranked according to their sensitivity to labor income growth ${ }^{6}, \beta L$. Finally, $\mathrm{HC}$ is obtained as the difference in equally weighted returns on two portfolios, ceiling and floor quintiles of sorted firms using $\beta L$. This process essentially involves a zero investment strategy, buying the top quintile and selling the lowest quintile. The return differential represents the premium for human capital. Given in table 5 are the summary statistics of risk factors.

TABLE 5. Summary statistics of IS and other risk factors

\begin{tabular}{|c|c|c|c|c|c|c|c|c|c|}
\hline & \multicolumn{2}{|c|}{ Summary statistics } & \multicolumn{7}{|c|}{ Correlation coefficients } \\
\hline & Mean & Std. & Min & Max & MRP & IS & SMB & HML & $\mathrm{HC}$ \\
\hline MRP & 0.51 & 4.32 & -15.51 & 13.39 & 1 & & & & \\
\hline IS & 0.58 & 14.90 & -57.67 & 80.32 & $0.32 *$ & 1 & & & \\
\hline SMB & -1.24 & 2.62 & -8.52 & 9.09 & $-0.19 *$ & $0.08^{*}$ & 1 & & \\
\hline HML & -1.78 & 2.29 & -12.71 & 4.55 & $0.24 *$ & $0.08^{*}$ & $-0.45^{*}$ & 1 & \\
\hline $\mathrm{HC}$ & -0.10 & 5.28 & -15.66 & 17.30 & 0.06 & -0.02 & $-0.14^{*}$ & 0.00 & 1 \\
\hline
\end{tabular}

This table reports summary statistics (in percentages) of Market risk premium (MRP), Investor sentiment (IS), Small minus Big (SMB), High minus Low (HML), and Human capital (HC), with significance *at 1\% level. Monthly returns from 2000 to 2013.

Test Assets We form six Size-BM sorted portfolios (Gilbert, Ward \& Djajadikerta 2009); small-low, smallmedium, small-high, big-low, big-medium, and big-high. This is a year-end process resulting in asset portfolios for which monthly value weighted returns are calculated for the succeeding twelve months. Table 6 reports summary statistics of portfolios formed. 
TABLE 6. Summary statistics of test portfolios (P)

\begin{tabular}{|c|c|c|c|c|c|c|}
\hline \multicolumn{5}{|c|}{ Mean-Returns } & \multicolumn{2}{|c|}{ SD } \\
\hline BM & Small & \#Firms & Big & \#Firms & Small & Big \\
\hline$P_{L}$ & -0.97 & 94 & -0.52 & 136 & 5.56 & 5.45 \\
\hline $\mathrm{P}_{\mathrm{M}}$ & -0.25 & 107 & 0.14 & 122 & 5.12 & 5.15 \\
\hline $\mathrm{P}_{\mathrm{H}}$ & 0.32 & 143 & 0.46 & 86 & 5.61 & 6.31 \\
\hline Columnar average & -0.30 & 114 & 0.03 & 114 & & \\
\hline
\end{tabular}

This table reports returns of test portfolios formed and number of firms included. Portfolios are BM (Low/ Medium /High) and Size (Small/Big) sorted. \#F is the annual average number of firms.

Multifactor APT-Framework We test FF 3-Factor model extending with IS and HC risk factors, in an Arbitrage Pricing Theory (APT) setting. The estimated linear model takes the following form.

$$
R_{p t}-R_{f y}=\alpha+\beta_{p l} F_{l t}+\ldots+\beta_{p k} F_{k t}+e
$$

Where; $R_{p t}$ is the expected return on asset $p(p=1, \ldots$, $N)$ at time $\mathrm{t} ; R_{f t}$ is the return on the risk-free asset at time $\mathrm{t} ; F_{k}$ refers to $(1 \times \mathrm{k})$ vector of factors. The factors are market risk premium (MRP), SMB, HML, HC and investor sentiment (IS). MRP is the return on the market portfolio above risk free rate, and market portfolio is proxied by the Kuala Lumpur Composite Index (KLCI). $\beta \mathrm{s}$ are the factor sensitivities to excess returns of $p^{\text {th }}$ portfolio. We apply dynamic Ordinary Least Squares (DOLS) for cointegrated panel data (Stock \& Watson 1993; Kao \& Chiang 2000) with homogeneous long-run covariance structure across portfolios. We test the portfolios using the DOLS estimations, with an objective of evaluating pricing efficiency of models.

\section{RESULTS}

The correlation coefficients in the Table 5 reveal the independence of the risk factors, except the moderate negative correlation of SMB and HML. HC has a low mean return and shows a weak negative relationship with SMB. It shows that there are returns for human capital when size catches low premium. Higher variability of IS, relative to other factors, is due to the variation of the sentiment index which do not reflect a return premium.
MRP and IS show that market trend and sentiment shifts are marginally related and take a similar direction. Within the summary statistics reported in Table 6, the number of firms shows that many big firms are grouped in the low BM category while many small firms are in the high BM category suggesting that small firms have a tendency to be under-valued while big firms have the tendency to be over-valued. Average returns for groups show that big firms outperform small across all cases. This suggests a negative size premium, or a reversal of size effect in Malaysia. More important, the value stock portfolios (i.e., high BM) outperform growth stock portfolios (i.e., Low BM) across all the cases in panels reported, suggesting presence of a value premium.

Adjusted $\mathrm{R}^{2}$ in time series regressions estimated for each of the six portfolios (Table 7) reveal that the model with IS covers return variations substantially. HC, whilst negatively related, is insignificant in all the portfolios, the human capital has no role. Factor loadings of SMB increase in the small category, indicating the evidence of size effect. The impact of BM shows a decrease in low BM stocks which means high BM stocks have high returns, and is consistent with prior findings in US (Fama \& French 1993). The increased intercept in high BM category suggests that the model has been unsuccessful in capturing BM effect, however intercept is insignificant in all of the portfolios. Both IS and MRP show their significance across all size and BM categories. Thus, we look at further time series estimations to compare and analyze model efficiency. Table 8 and 9 report estimations of capital asset pricing model (CAPM) FF three factor model, and multifactor APT estimations.

TABLE 7. Regression results

\begin{tabular}{|c|c|c|c|c|c|c|c|}
\hline & MRP & SMB & HML & IS & $\mathrm{HC}$ & Cons & Adj. $R^{2}$ \\
\hline $\mathrm{PS} / \mathrm{L}$ & $0.797 *$ & $0.841^{*}$ & -0.004 & $0.093^{*}$ & -0.050 & 0.006 & 0.624 \\
\hline $\mathrm{PS} / \mathrm{M}$ & $\begin{array}{c}0.767 * \\
(0.000)\end{array}$ & $\begin{array}{l}0.823^{*} \\
(0.000)\end{array}$ & $\begin{array}{c}0.226 \\
(0.041)\end{array}$ & $\begin{array}{l}0.096^{*} \\
(0.000)\end{array}$ & $\begin{array}{l}-0.027 \\
(0.522)\end{array}$ & $\begin{array}{c}0.005 \\
(0.522)\end{array}$ & 0.714 \\
\hline PS/H & $\begin{array}{c}0.824^{*} \\
(0.000)\end{array}$ & $\begin{array}{c}0.916^{*} \\
(0.000)\end{array}$ & $\begin{array}{l}0.608^{*} \\
(0.000)\end{array}$ & $\begin{array}{c}0.096^{*} \\
(0.000)\end{array}$ & $\begin{array}{l}-0.037 \\
(0.411)\end{array}$ & $\begin{array}{c}0.018 \\
(0.411)\end{array}$ & 0.726 \\
\hline $\mathrm{PB} / \mathrm{L}$ & $\begin{array}{c}0.962^{*} \\
(0.000)\end{array}$ & $\begin{array}{c}0.193 \\
(0.042)\end{array}$ & $\begin{array}{l}0.076^{*} \\
(0.414)\end{array}$ & $\begin{array}{c}-0.032 \\
(0.000)\end{array}$ & $\begin{array}{c}-0.032 \\
(0.460)\end{array}$ & $\begin{array}{c}0.009 \\
(0.460)\end{array}$ & 0.727 \\
\hline $\mathrm{PB} / \mathrm{M}$ & $\begin{array}{c}0.843^{*} \\
(0.000)\end{array}$ & $\begin{array}{c}0.073 \\
(0.359)\end{array}$ & $\begin{array}{l}0.302 * \\
(0.007)\end{array}$ & $\begin{array}{l}0.080^{*} \\
(0.000)\end{array}$ & $\begin{array}{l}-0.042 \\
(0.323)\end{array}$ & $\begin{array}{c}0.001 \\
(0.323)\end{array}$ & 0.717 \\
\hline $\mathrm{PB} / \mathrm{H}$ & $\begin{array}{c}0.942 * \\
(0.000)\end{array}$ & $\begin{array}{c}0.228 \\
(0.071)\end{array}$ & $\begin{array}{l}0.596^{*} \\
(0.000)\end{array}$ & $\begin{array}{l}0.109^{*} \\
(0.000)\end{array}$ & $\begin{array}{c}-0.062 \\
(0.252)\end{array}$ & $\begin{array}{c}0.010 \\
(0.252)\end{array}$ & 0.687 \\
\hline
\end{tabular}

This table reports coefficients of risk factors with associated p-values, estimated in time series regressions for each portfolio. $\mathrm{Pi} / \mathrm{j}$ are the size-BM sorted portfolios, where ' $\mathrm{i}$ ' is size (small/big) and ' $\mathrm{j}$ ' is BM (low/medium/high). Significance * at $1 \%$ level. 
TABLE 8. Time series regression: Small category

\begin{tabular}{|c|c|c|c|c|c|c|c|c|}
\hline $\mathrm{BM}$ & & MRP & SMB & HML & IS & $\mathrm{HC}$ & Cons. & Adj. $R^{2}$ \\
\hline \multirow[t]{7}{*}{ Low } & CAPM & $\begin{array}{l}0.802 * \\
(0.000)\end{array}$ & & & & & $\begin{array}{l}-0.016^{*} \\
(0.000)\end{array}$ & 0.386 \\
\hline & MRP+IS & $\begin{array}{l}0.668^{*} \\
(0.000)\end{array}$ & & & $\begin{array}{l}0.119^{*} \\
(0.000)\end{array}$ & & $\begin{array}{l}-0.016^{*} \\
(0.002)\end{array}$ & 0.474 \\
\hline & $\mathrm{MRP}+\mathrm{IS}+\mathrm{HC}$ & $\begin{array}{l}0.670^{*} \\
(0.000)\end{array}$ & & & $\begin{array}{l}0.118^{*} \\
(0.000)\end{array}$ & $\begin{array}{l}-0.106 \\
(0.083)\end{array}$ & $\begin{array}{l}-0.016^{*} \\
(0.000)\end{array}$ & 0.481 \\
\hline & $\mathrm{FF}$ & $\begin{array}{l}0.907^{*} \\
(0.000)\end{array}$ & $\begin{array}{l}0.963^{*} \\
(0.000)\end{array}$ & $\begin{array}{l}0.061 \\
(0.673)\end{array}$ & & & $\begin{array}{l}-0.004 \\
0.422\end{array}$ & 0.572 \\
\hline & $\mathrm{FF}+\mathrm{IS}$ & $\begin{array}{l}0.798^{*} \\
(0.000)\end{array}$ & $\begin{array}{l}0.859^{*} \\
(0.000)\end{array}$ & $\begin{array}{l}0.005 \\
(0.972)\end{array}$ & $\begin{array}{l}0.093^{*} \\
(0.000)\end{array}$ & & $\begin{array}{l}-0.006 \\
0.170\end{array}$ & 0.624 \\
\hline & $\mathrm{FF}+\mathrm{HC}$ & $\begin{array}{l}0.906^{*} \\
(0.000)\end{array}$ & $\begin{array}{l}0.946^{*} \\
(0.000)\end{array}$ & $\begin{array}{l}0.052 \\
(0.719)\end{array}$ & & $\begin{array}{l}-0.049 \\
(0.386)\end{array}$ & $\begin{array}{l}-0.004 \\
(0.375)\end{array}$ & 0.572 \\
\hline & $\mathrm{FF}+\mathrm{IS}+\mathrm{HC}$ & $\begin{array}{l}0.797^{*} \\
(0.000)\end{array}$ & $\begin{array}{l}0.841^{*} \\
(0.000)\end{array}$ & $\begin{array}{l}-0.004 \\
(0.975)\end{array}$ & $\begin{array}{l}0.093^{*} \\
(0.000)\end{array}$ & $\begin{array}{l}-0.050 \\
(0.342)\end{array}$ & $\begin{array}{l}-0.006 \\
(0.144)\end{array}$ & 0.624 \\
\hline \multirow[t]{7}{*}{ Medium } & CAPM & $\begin{array}{l}0.808^{*} \\
(0.000)\end{array}$ & & & & & $\begin{array}{l}-0.009^{*} \\
(0.004)\end{array}$ & 0.464 \\
\hline & $\mathrm{MRP}+\mathrm{IS}$ & $\begin{array}{l}0.672^{*} \\
(0.000)\end{array}$ & & & $\begin{array}{l}0.121^{*} \\
(0.000)\end{array}$ & & $\begin{array}{l}-0.009^{*} \\
(0.001)\end{array}$ & 0.573 \\
\hline & $\mathrm{MRP}+\mathrm{IS}+\mathrm{HC}$ & $\begin{array}{l}0.673^{*} \\
(0.000)\end{array}$ & & & $\begin{array}{l}0.120^{*} \\
(0.000)\end{array}$ & $\begin{array}{l}-0.082 \\
(0.113)\end{array}$ & $\begin{array}{l}-0.009^{*} \\
(0.001)\end{array}$ & 0.577 \\
\hline & $\mathrm{FF}$ & $\begin{array}{l}0.881^{*} \\
(0.000)\end{array}$ & $\begin{array}{l}0.941^{*} \\
(0.000)\end{array}$ & $\begin{array}{l}0.290 \\
(0.018)\end{array}$ & & & $\begin{array}{l}0.007 \\
0.055\end{array}$ & 0.649 \\
\hline & $\mathrm{FF}+\mathrm{IS}$ & $\begin{array}{l}0.768^{*} \\
(0.000)\end{array}$ & $\begin{array}{l}0.833^{*} \\
(0.000)\end{array}$ & $\begin{array}{l}0.231 \\
(0.036)\end{array}$ & $\begin{array}{l}0.096^{*} \\
(0.000)\end{array}$ & & $\begin{array}{l}0.005 \\
(0.147)\end{array}$ & 0.715 \\
\hline & $\mathrm{FF}+\mathrm{HC}$ & $\begin{array}{l}0.880^{*} \\
(0.000)\end{array}$ & $\begin{array}{l}0.931^{*} \\
(0.000)\end{array}$ & $\begin{array}{l}0.285 \\
(0.021)\end{array}$ & & $\begin{array}{l}-0.026 \\
(0.583)\end{array}$ & $\begin{array}{l}0.007 \\
(0.065)\end{array}$ & 0.647 \\
\hline & $\mathrm{FF}+\mathrm{IS}+\mathrm{HC}$ & $\begin{array}{l}0.767 * \\
(0.000)\end{array}$ & $\begin{array}{l}0.823^{*} \\
(0.000)\end{array}$ & $\begin{array}{l}0.226 \\
(0.041)\end{array}$ & $\begin{array}{l}0.096^{*} \\
(0.000)\end{array}$ & $\begin{array}{l}-0.027 \\
(0.522)\end{array}$ & $\begin{array}{l}0.005 \\
(0.170)\end{array}$ & 0.714 \\
\hline \multirow[t]{7}{*}{ High } & CAPM & $\begin{array}{l}0.905^{*} \\
(0.000)\end{array}$ & & & & & $\begin{array}{l}-0.004 \\
(0.256)\end{array}$ & 0.485 \\
\hline & $\mathrm{MRP}+\mathrm{IS}$ & $\begin{array}{l}0.764^{*} \\
(0.000)\end{array}$ & & & $\begin{array}{l}0.125^{*} \\
(0.000)\end{array}$ & & $\begin{array}{l}-0.004 \\
(0.206)\end{array}$ & 0.581 \\
\hline & $\mathrm{MRP}+\mathrm{IS}+\mathrm{HC}$ & $\begin{array}{l}0.766^{*} \\
(0.000)\end{array}$ & & & $\begin{array}{l}0.124^{*} \\
(0.000)\end{array}$ & $\begin{array}{l}-0.099 \\
(0.324)\end{array}$ & $\begin{array}{l}-0.004 \\
(0.191)\end{array}$ & 0.587 \\
\hline & $\mathrm{FF}$ & $\begin{array}{l}0.938^{*} \\
(0.000)\end{array}$ & $\begin{array}{l}1.037^{*} \\
(0.000)\end{array}$ & $\begin{array}{l}0.673^{*} \\
(0.000)\end{array}$ & & & $\begin{array}{l}0.021^{*} \\
(0.000)\end{array}$ & 0.671 \\
\hline & $\mathrm{FF}+\mathrm{IS}$ & $\begin{array}{l}0.825^{*} \\
(0.000)\end{array}$ & $\begin{array}{l}0.929 * \\
(0.000)\end{array}$ & $\begin{array}{l}0.615^{*} \\
(0.000)\end{array}$ & $\begin{array}{l}0.096^{*} \\
(0.000)\end{array}$ & & $\begin{array}{l}0.019^{*} \\
(0.000)\end{array}$ & 0.727 \\
\hline & $\mathrm{FF}+\mathrm{HC}$ & $\begin{array}{l}0.938^{*} \\
(0.000)\end{array}$ & $\begin{array}{l}1.025^{*} \\
(0.000)\end{array}$ & $\begin{array}{l}0.667^{*} \\
(0.000)\end{array}$ & & $\begin{array}{l}-0.036 \\
(0.470)\end{array}$ & $\begin{array}{l}0.021^{*} \\
(0.000)\end{array}$ & 0.670 \\
\hline & $\mathrm{FF}+\mathrm{IS}+\mathrm{HC}$ & $\begin{array}{l}0.824^{*} \\
(0.000)\end{array}$ & $\begin{array}{l}0.916^{*} \\
(0.000)\end{array}$ & $\begin{array}{l}0.608^{*} \\
(0.000)\end{array}$ & $\begin{array}{l}0.096^{*} \\
(0.000)\end{array}$ & $\begin{array}{l}-0.037 \\
(0.411)\end{array}$ & $\begin{array}{l}0.018^{*} \\
(0.000)\end{array}$ & 0.726 \\
\hline
\end{tabular}

Table reports regression results for size-BM sorted (small-low/small-medium/small-high) 3 portfolios. $P$-values are reported in parenthesis. Significance * at $1 \%$ level.

The results reveal that IS is significant across all categories of portfolios, suggesting that it is a source of systemic risk, and is consistent with Changsheng and Yongfeng (2012). However, small stocks show a marginally higher sensitivity to investor sentiment than the big stocks. Hence, sentiment is significant in case of stocks with opaque characteristics, perhaps the source of this gap may indicate liquidity biasness as the liquidity has role in Malaysian market (Jais \& Gunathilaka 2016). MRP, in the single risk factor CAPM, shows the lowest $\mathrm{R}^{2}$ of 0.386 . In a combined model, MRP with IS in an APT setting shows a substantial improvement. FF three factor model shows a higher efficiency in small stock portfolios (minimum adjusted $\mathrm{R}^{2}$ of 0.572 ) than the joint power of MRP and IS (minimum adjusted $\mathrm{R}^{2}$ of 0.474 ). However, a reverse is observed in the big category (FF and MRP+IS show minimum adjusted $\mathrm{R}^{2}$ of 0.629 and 0.652 respectively). This suggests that IS uniformly explains the returns while SMB better explains the variation in small stocks than big stocks. HML become significant in medium to high BM portfolios indicating a strong value premium. Is risk factor has the ability of capturing the impact of both size and value factors. The results indicate that the highest model efficiency is achieved by a four factor model, the 
FF model augmented with IS risk. The $\mathrm{R}^{2}$ of this four factor model achieves a maximum of $72.8 \%$ with a minimum of $62.4 \%$. The negative human capital risk factor shows insignificance, and it does not improve model efficiency. Thus, we dismiss the hypothesis that there is a return for human capital in Malaysian market. CAPM's $\mathrm{R}^{2}$ ranges from $38.6 \%$ to $48.5 \%$ in small category (Table 8 ) while it ranges from $58.5 \%$ to $68 \%$ in big (Table 9). Note that the constituents in the proxy for market portfolio (KLCI) are the big firms, and they are the liquid stocks in the market. It suggests that CAPM is efficient in liquidity than illiquidity.

TABLE 9. Time series regression: Big category

\begin{tabular}{|c|c|c|c|c|c|c|c|c|}
\hline BM & & MRP & SMB & HML & IS & $\mathrm{HC}$ & Cons. & Adj. $R^{2}$ \\
\hline \multirow[t]{7}{*}{ Low } & CAPM & $\begin{array}{l}0.802^{*} \\
(0.000)\end{array}$ & & & & & $\begin{array}{l}-0.013^{*} \\
(0.000)\end{array}$ & 0.680 \\
\hline & $\mathrm{MRP}+\mathrm{IS}$ & $\begin{array}{l}0.945^{*} \\
(0.000)\end{array}$ & & & $\begin{array}{l}0.083^{*} \\
(0.000)\end{array}$ & & $\begin{array}{l}-0.013 * \\
(0.000)\end{array}$ & 0.724 \\
\hline & $\mathrm{MRP}+\mathrm{IS}+\mathrm{HC}$ & $\begin{array}{l}0.946^{*} \\
(0.000)\end{array}$ & & & $\begin{array}{l}0.082 * \\
(0.000)\end{array}$ & $\begin{array}{l}-0.045 \\
(0.234)\end{array}$ & $\begin{array}{l}-0.013^{*} \\
(0.000)\end{array}$ & 0.724 \\
\hline & $\mathrm{FF}$ & $\begin{array}{l}1.053^{*} \\
(0.000)\end{array}$ & $\begin{array}{l}0.291^{*} \\
(0.005)\end{array}$ & $\begin{array}{l}0.146 \\
(0.228)\end{array}$ & & & $\begin{array}{l}-0.007 \\
(0.083)\end{array}$ & 0.691 \\
\hline & $\mathrm{FF}+\mathrm{IS}$ & $\begin{array}{l}0.963^{*} \\
(0.000)\end{array}$ & $\begin{array}{l}0.204 \\
(0.042)\end{array}$ & $\begin{array}{l}0.101 \\
(0.383)\end{array}$ & $\begin{array}{l}0.076^{*} \\
(0.000)\end{array}$ & & $\begin{array}{l}-0.009 \\
(0.019)\end{array}$ & 0.728 \\
\hline & $\mathrm{FF}+\mathrm{HC}$ & $\begin{array}{l}1.053^{*} \\
(0.000)\end{array}$ & $\begin{array}{l}0.279^{*} \\
(0.009)\end{array}$ & $\begin{array}{l}0.140 \\
(0.249)\end{array}$ & & $\begin{array}{l}-0.031 \\
(0.502)\end{array}$ & $\begin{array}{l}-0.007 \\
(0.073)\end{array}$ & 0.690 \\
\hline & $\mathrm{FF}+\mathrm{IS}+\mathrm{HC}$ & $\begin{array}{l}0.962 * \\
(0.000)\end{array}$ & $\begin{array}{l}0.193 \\
(0.058)\end{array}$ & $\begin{array}{l}0.094 \\
(0.414)\end{array}$ & $\begin{array}{l}0.076^{*} \\
(0.000)\end{array}$ & $\begin{array}{l}-0.032 \\
(0.460)\end{array}$ & $\begin{array}{l}-0.009 \\
(0.016)\end{array}$ & 0.727 \\
\hline \multirow[t]{7}{*}{ Medium } & CAPM & $\begin{array}{l}0.964^{*} \\
(0.000)\end{array}$ & & & & & $\begin{array}{l}-0.006 \\
(0.018)\end{array}$ & 0.655 \\
\hline & $\mathrm{MRP}+\mathrm{IS}$ & $\begin{array}{l}0.870^{*} \\
(0.000)\end{array}$ & & & $\begin{array}{l}0.083^{*} \\
(0.000)\end{array}$ & & $\begin{array}{l}-0.006 \\
(0.010)\end{array}$ & 0.705 \\
\hline & $\mathrm{MRP}+\mathrm{IS}+\mathrm{HC}$ & $\begin{array}{l}0.871^{*} \\
(0.000)\end{array}$ & & & $\begin{array}{l}0.083^{*} \\
(0.000)\end{array}$ & $\begin{array}{l}-0.047 \\
(0.270)\end{array}$ & $\begin{array}{l}-0.006^{*} \\
(0.010)\end{array}$ & 0.706 \\
\hline & $\mathrm{FF}$ & $\begin{array}{l}0.938^{*} \\
(0.000)\end{array}$ & $\begin{array}{l}0.179 \\
(0.081)\end{array}$ & $\begin{array}{l}0.359 * \\
(0.003)\end{array}$ & & & $\begin{array}{l}0.003 \\
(0.446)\end{array}$ & 0.671 \\
\hline & $\mathrm{FF}+\mathrm{IS}$ & $\begin{array}{l}0.843^{*} \\
(0.000)\end{array}$ & $\begin{array}{l}0.089 \\
(0.359)\end{array}$ & $\begin{array}{l}0.310^{*} \\
(0.005)\end{array}$ & $\begin{array}{l}0.080^{*} \\
(0.000)\end{array}$ & & $\begin{array}{l}0.001 \\
(0.800)\end{array}$ & 0.717 \\
\hline & $\mathrm{FF}+\mathrm{HC}$ & $\begin{array}{l}0.938^{*} \\
(0.000)\end{array}$ & $\begin{array}{l}0.165 \\
(0.113)\end{array}$ & $\begin{array}{l}0.351 * \\
(0.003)\end{array}$ & & $\begin{array}{l}-0.041 \\
(0.372)\end{array}$ & $\begin{array}{l}0.003 \\
(0.506)\end{array}$ & 0.670 \\
\hline & $\mathrm{FF}+\mathrm{IS}+\mathrm{HC}$ & $\begin{array}{l}0.843^{*} \\
(0.000)\end{array}$ & $\begin{array}{l}0.073 \\
(0.452)\end{array}$ & $\begin{array}{l}0.302 * \\
(0.007)\end{array}$ & $\begin{array}{l}0.080^{*} \\
(0.000)\end{array}$ & $\begin{array}{l}-0.042 \\
(0.323)\end{array}$ & $\begin{array}{l}0.001 \\
(0.881)\end{array}$ & 0.717 \\
\hline \multirow[t]{7}{*}{ High } & CAPM & $\begin{array}{l}1.117^{*} \\
(0.000)\end{array}$ & & & & & $\begin{array}{l}-0.003 \\
(0.291)\end{array}$ & 0.585 \\
\hline & $\mathrm{MRP}+\mathrm{IS}$ & $\begin{array}{l}0.985^{*} \\
(0.000)\end{array}$ & & & $\begin{array}{l}0.117 * \\
(0.000)\end{array}$ & & $\begin{array}{l}-0.003 \\
(0.248)\end{array}$ & 0.652 \\
\hline & $\mathrm{MRP}+\mathrm{IS}+\mathrm{HC}$ & $\begin{array}{l}0.986^{*} \\
(0.000)\end{array}$ & & & $\begin{array}{l}0.117^{*} \\
(0.000)\end{array}$ & $\begin{array}{l}-0.078 \\
(0.167)\end{array}$ & $\begin{array}{l}-0.004 \\
(0.236)\end{array}$ & 0.654 \\
\hline & $\mathrm{FF}$ & $\begin{array}{l}1.072^{*} \\
(0.000)\end{array}$ & $\begin{array}{l}0.373^{*} \\
(0.005)\end{array}$ & $\begin{array}{l}0.674^{*} \\
(0.000)\end{array}$ & & & $\begin{array}{l}0.013 * \\
(0.007)\end{array}$ & 0.629 \\
\hline & $\mathrm{FF}+\mathrm{IS}$ & $\begin{array}{l}0.943^{*} \\
(0.000)\end{array}$ & $\begin{array}{l}0.250 \\
(0.045)\end{array}$ & $\begin{array}{l}0.608^{*} \\
(0.000)\end{array}$ & $\begin{array}{l}0.109 * \\
(0.000)\end{array}$ & & $\begin{array}{l}0.011 \\
(0.019)\end{array}$ & 0.686 \\
\hline & $\mathrm{FF}+\mathrm{HC}$ & $\begin{array}{l}1.071^{*} \\
(0.000)\end{array}$ & $\begin{array}{l}0.352^{*} \\
(0.010)\end{array}$ & $\begin{array}{l}0.663^{*} \\
(0.000)\end{array}$ & & $\begin{array}{l}-0.061 \\
(0.304)\end{array}$ & $\begin{array}{l}0.013^{*} \\
(0.010)\end{array}$ & 0.630 \\
\hline & $\mathrm{FF}+\mathrm{IS}+\mathrm{HC}$ & $\begin{array}{l}0.942^{*} \\
(0.000)\end{array}$ & $\begin{array}{l}0.228 \\
(0.071)\end{array}$ & $\begin{array}{l}0.596^{*} \\
(0.000)\end{array}$ & $\begin{array}{l}0.109^{*} \\
(0.000)\end{array}$ & $\begin{array}{l}-0.062 \\
(0.252)\end{array}$ & $\begin{array}{l}0.010 \\
(0.027)\end{array}$ & 0.687 \\
\hline
\end{tabular}

Table reports regression results for Big-low/middle/high BM sorted 3 portfolios. $P$-values are reported in parenthesis. Significance $*$ at $1 \%$ level.

The insignificant $\mathrm{HC}$ in individual portfolios (i.e. in time series estimations) become significant in panel estimations (Table 10), yet it shows a marginal improvement (increment in $\mathrm{R}^{2}$ ) only. CAPM in a single factor model covers a substantial proportion $\left(\mathrm{R}^{2}=0.545\right)$ of the variation, and FF model's $\mathrm{R}^{2}$ is 0.63 . However, market risk premium (MRP) and IS in an APT setting, shows a similar efficiency with $\mathrm{R}^{2}$ of 0.621 . It suggests that IS risk captured by the index in this paper has the ability of capturing a variation similar to the joint power of size and value anomalies. However, the optimal efficiency $\left(\mathrm{R}^{2}\right.$ of 0.673 ) among the models tested in this study is a four factor model that consist of FF 3 factors and IS. 
TABLE 10. DOLS estimations

\begin{tabular}{|c|c|c|c|c|c|c|}
\hline & MRP & SMB & HML & IS & $\mathrm{HC}$ & Adj. $\mathrm{R}^{2}$ \\
\hline CAPM & $\begin{array}{l}0.932 * \\
(0.000)\end{array}$ & & & & & 0.545 \\
\hline $\mathrm{MRP}+\mathrm{IS}$ & $\begin{array}{l}0.802^{*} \\
(0.000)\end{array}$ & & & $\begin{array}{l}0.105^{*} \\
(0.000)\end{array}$ & & 0.614 \\
\hline $\mathrm{MRP}+\mathrm{IS}+\mathrm{HC}$ & $\begin{array}{l}0.809^{*} \\
(0.000)\end{array}$ & & & $\begin{array}{l}0.101 * \\
(0.000)\end{array}$ & $\begin{array}{l}-0.127^{*} \\
(0.000)\end{array}$ & 0.621 \\
\hline FF & $\begin{array}{l}0.975^{*} \\
(0.000)\end{array}$ & $\begin{array}{l}0.725^{*} \\
(0.000)\end{array}$ & $\begin{array}{l}0.416^{*} \\
(0.000)\end{array}$ & & & 0.630 \\
\hline $\mathrm{FF}+\mathrm{IS}$ & $\begin{array}{l}0.854^{*} \\
(0.000)\end{array}$ & $\begin{array}{l}0.586^{*} \\
(0.000)\end{array}$ & $\begin{array}{l}0.351^{*} \\
(0.000)\end{array}$ & $\begin{array}{l}0.0897 * \\
(0.000)\end{array}$ & & 0.673 \\
\hline $\mathrm{FF}+\mathrm{IS}+\mathrm{HC}$ & $\begin{array}{l}0.855^{*} \\
(0.000)\end{array}$ & $\begin{array}{l}0.556^{*} \\
(0.000)\end{array}$ & $\begin{array}{l}0.335^{*} \\
(0.000)\end{array}$ & $\begin{array}{l}0.886^{*} \\
(0.000)\end{array}$ & $\begin{array}{l}-0.071 * \\
(0.000)\end{array}$ & 0.675 \\
\hline
\end{tabular}

This table reports coefficients and associated p-values (in parenthesis) of risk factors. Significance * at 1\% level. Estimations follow dynamic OLS regressions for a panel of 6 portfolios, for CAPM and other APT models.

Turning to the possible argument of inconsistency of results in view of return volatility of the market portfolio proxied by KLCI, we test the influence of IS on market risk premium on alternative indices of Bursa Malaysia. Bursa reports an index of top firm portfolios (KLCI) and middle
70 firms (MID70) among others. Bursa's EMAS index is a total reflection of KLCI, MID70 and the small cap index. We perform single factor OLS estimations on excess returns on each of the three indices, the results are explained in the Table 11

TABLE 11. Regression results

\begin{tabular}{lcccc}
\hline & Cons. & IS & Adj. $\mathrm{R}^{2}$ & Durbin Watson \\
\hline KLCI & $0.003(0.385)$ & $0.09 *(0.000)$ & 0.099 & 1.82 \\
EMAS & $0.003(0.465)$ & $0.11 *(0.000)$ & 0.117 & 1.74 \\
MID70 & $0.003(0.013)$ & $0.13 *(0.000)$ & 0.136 & 1.71 \\
\hline
\end{tabular}

This table reports impact of IS on excess returns on KLCI, EMAS and MID70, the market indices of Bursa Malaysia. Coefficients of OLS estimation results are reported with p-values in parenthesis. Significance * at $1 \%$ level.

The objective of this estimation is to ascertain the impact of IS on excess returns of different market portfolios, while the KLCI is a broad based index, Mid 70 reflects a portfolio with relatively small to middle capitalized firms. Furthermore, EMAS reflects a collection of a large number of small and big firms. The results reveal a consistent significance of IS variable, reflecting its power of explaining excess returns on all the market portfolios. Thus, we conclude by means of different analyses discussed above, that the seven-variable index proposed in this study has the ability of capturing the Malaysian market sentiment and explaining returns in the cross section. In particular, it has the ability of explaining returns on hard-to-predict stocks, for instance, small stocks than big stocks. Adjusted $\mathrm{R}^{2}$ in table 11 also explains that the IS, as a single factor, explains about $10 \%$ of the total variation of excess returns irrespective of portfolio's size, value or other characteristics.

\section{MANAGERIAL IMPLICATIONS}

Results of the study confirm that investor sentiment has a significant role of in the Malaysian equity market.
Furthermore, stocks with opaque characteristics are highly subjected to the influence of sentiment. It explains the gravity of the rational market assumption, and fundamental analysis may partially contribute to investment managers decisions. It is a potential cause of concern that the anomalies reported do limit the arbitrage opportunities. Investors can avoid speculative markets identifying the sentiment information, which is wealthy and imperative for the market's self-regulation. It may be significant that investment managers track the sentiment in view of the market instability and misallocation of scarce resources.

\section{CONCLUSION}

This study assembles evidence that changing investor sentiment has significant pricing implications in the Malaysian market. Under the assumption that aggregate market proxies accumulate individual investor sentiment, we propose a seven variable $(7-\mathrm{V})$ composite sentiment index. First, it demonstrates the robustness in multiple factor pricing models. Even though there is no agreement for optimal number of proxies to form a sentiment index, we rely on the demonstrated robustness of the 
7-V index. Small are good candidates, and are exposed to sentiment than their counterpart, big capitalization stocks. Yet, regardless of the stock's exposure to other risk characteristics like size, BM and human capital, sentiment risk shows its significance in explaining returns in cross section. Second, it shows predictability of the popular Malaysian consumer sentiment index through Granger causation. Furthermore, it demonstrates significance in explaining market excess returns of different size-liquidity based portfolios (i.e. KLCI, MID70 and EMAS) in Bursa Malaysia.

Our results do not support the argument that the labor market influences the capital market, and thus the human capital risk factor is not priced. Perhaps, the ownership structure with closely-held and state-owned institutional setting of the market may conclude it is an insignificant factor. Evidence suggests that inefficiency of the CAPM is related to opaque characteristics of stocks. It has lower performance in small and low BM stocks. A strong value anomaly is evident, and the joint power of SMB and HML relative to sentiment risk is prominent in small capitalization stocks. Apparently, evidence favors the application of a four factor model, FF three factor model augmented with investor sentiment risk, for improved efficiency. Nevertheless, a four factor model may not be an absolute solution for investment management in Malaysia, in view of the unexplained component of return variation across all the portfolios. This four factor model captures more than $2 / 3^{\text {rd }}$ of the total variation in the cross-section returns. This also directs research in to the existence of further market anomalies.

\section{ENDNOTE}

Source. Department of statistics, Malaysia.

2 TURN: natural log of raw turnover ratio, DivP: log difference of the average market-to-book ratios of dividend payers and nonpayer (dividend premium), CEFD: average difference between the net asset value of closed-end stock fund shares and their market prices, NIPO: number of initial public offers, RIPO: first-day IPO returns and EITI: equity issues for total issues.

3 Department of Statistics, Malaysia

4 Bivariate linear autoregressive model: $C S I_{t}=\sum_{i=1}^{p} \beta_{1 j} C S I_{t-j}+\varepsilon_{t}$ Where, $p$ is the maximum number of $j$ lags included, and $\beta$ $\mathrm{s}$ are coefficients of the model.

$5 \quad E(R)_{i}=\infty_{i t}+\beta_{i} L_{t}+\varepsilon_{i}$

6 We use the method of Gollin (2002) for ascertaining labor income; the aggregate labor payment is adjusted to reflect the total workforce.

\section{ACKNOWLEDGEMENT}

Financial support from the University Malaysia Sarawak and Digital Sarawak CoE [UHSB/B-AM2018/083] are gratefully acknowledged. All remaining flaws are the responsibilities of the authors.

\section{REFERENCES}

Amihud, Y. \& Mendelson, H. 1986. Asset pricing and the bid-ask spread. Journal of Financial Economics 17(2): 223-249.

Amran, N.A. \& Ahmad, A.C. 2013. Effects of ownership structure on Malaysian companies performance. Asian Journal of Accounting and Governance 4: 51-60.

Baker, M. \& Wurgler, J. 2006. Investor sentiment and the cross-section of stock returns. Journal of Finance 61(4): 1645-1680.

Baker, M. \& Wurgler, J. 2007. Investor sentiment in the stock market. Journal of Economic Perspectives 21(2): 129151.

Bandopadhyaya, A. \& Jones, A.L. 2006. Measuring investor sentiment in equity markets. Journal of Asset Management 7(3): 208-215.

Banz, R. 1981. The relationship between returns and market value of common stocks. Journal of Financial Economics 9: 3-18.

Bessembinder, H. \& Seguin, P.J. 1993. Price volatility, trading volume, and market depth: Evidence from futures markets. Journal of Financial and Quantitative Analysis 28(1): 21-39.

Betermier, S., Jansson, T., Parlour, C. \& Walden, J. 2012. Hedging labor income risk. Journal of Financial Economics 105(3): 622-639.

Brown, G.W. \& Cliff, M.T. 2004. Investor sentiment and the near-term stock market. Journal of Empirical Finance 11(1): 1-27.

Campbell, J.Y. 1996. Understanding risk and return. Journal of Political Economy 104(2): 298-345.

Campbell, S.D. \& Korniotis, G.M. 2008. The human capital that matters: expected returns and the income of affluent households. Federal Reserve Board, Finance and Economics Discussion Series. Available at http://www. federalreserve.gov/pubs/feds/2008/200809.

Campelo, A., Friedman, J.S., Lima, S., Ozyildirim, A. \& Picchetti, P. 2013. Tracking business cycles in Brazil with composite indexes of coincident and leading economic indicators. Economics Program Working Paper Series 13(6): 1-28.

Carhart, M.M. 1997. On persistence in mutual fund performance. Journal of Finance 52(1): 57-82.

Chae, J. \& Yang, C. 2008. Failure of asset pricing models: Transaction cost, irrationality, or missing factors. Available at SSRN: http://ssrn.com/abstract=1089744.

Changsheng, H. \& Yongfeng, W. 2012. Investor sentiment and assets valuation. Systems Engineering Procedia 3(2012): 166-171.

Chen, L. \& Zhang, L.U. 2010. A better three-factor model that explains more anomalies. Journal of Finance 65(2): 563-595.

Chiang, T.C. \& Zheng, D. 2010. An empirical analysis of herd behavior in global stock markets. Journal of Banking and Finance 34(8): 1911-1921.

Christie, W.G. \& Huang, R.D. 1995. Following the pied piper: Do individual returns herd around the market? Financial Analysts Journal 51(4): 31-37.

Da, Z. Engelberg, J. \& Gao, P. 2014. The sum of all FEARS: Investor sentiment and asset prices. Review of Financial Studies 0(0): 1-40.

Dempsey, M. 2013. The capital asset pricing model: the history of a failed revolutionary idea in finance? Abacus 49(1): $7-23$. 
Fama, E.F. 1998. Market efficiency, long-term returns and behavioral finance. Journal of Financial Economics 49(1998): 283-306.

Fama, E.F. \& French, K.R. 1993. Common risk factors in the returns on stocks and bonds. Journal of Financial Economics 33(1993): 3-56.

Feldman, T. 2010. A more predictive index of market sentiment. Journal of Behavioral Finance 11(4): 211-223.

Finter, P., Niessen, R.A. \& Ruenzi, S. 2011. The impact of investor sentiment on the German stock market. CFR Working Paper 10-03 October, Centre for financial research, University of Cologne, Cologne.

Fong, W.M. \& Toh, B. 2014. Investor sentiment and the MAX effect. Journal of Banking and Finance 46(1): 190-201.

Foong, S.S. \& Goh, K.L. 2010. Measuring the cost of equity of emerging market firms: The case of Malaysia. Asian Academy of Management Journal of Accounting and Finance 6(1): 25-46.

Gilbert, N.V., Ward, B.D. \& Djajadikerta, H.G. 2009. Size, $\mathrm{BM}$, and momentum effects and the robustness of the Fama-French three-factor model: Evidence from New Zealand. International Journal of Managerial Finance 5(2): 179-200.

Gollin, D. 2002. Getting income shares right. Journal of Political Economy 110(2): 458-474.

Huang, D., Jiang, F., Tu, J. \& Zhou, G. 2013. Investor sentiment aligned: A powerful predictor of stock returns. Available at http://ssrn/abs.231161.

Jaganathan, R. \& Wang, Z. 1996. The conditional CAPM and the cross-section of expected returns. Journal of Finance 51(1): 3-54.

Jais, M. \& Gunathilaka, C. 2016. Illiquidity exposure of size and value in Malaysian equity returns. International Journal of Business and Finance Research 10(2): 81-90.

Jarita, D. \& Salina, H.K. 2009. Herd behaviour in Malaysian capital market: An empirical analysis. Journal of Applied Economic Sciences 4(1): 45-57.

Jegadeesh, N. \& Titman, S. 1993. Returns to buying winners and selling losers: Implications for stock market efficiency. Journal of Finance 48(1): 65-91.

Jun, S.G., Marathe, A. \& Shawky, H. 2003. Liquidity and stock returns in emerging equity markets. Emerging Markets Review 4(1): 1-24.

Kao, C. \& Chiang, M.H. 2000. On the estimation and inference of a cointegrated regression in panel data. Advances in Econometrics 15: 179-222.

Kim, S.H., Kim, D. \& Shin, H.S. 2012. Evaluating asset pricing models in the Korean stock market. Pacific Basin Finance Journal 20(2): 198-227.

Kumar, A. \& Lee, C.M.C. 2006. Retail investor sentiment and return co-movements. Journal of Finance 61(5): 24512486.

Lam, K.S.K. \& Tam, L.H.K. 2011. Liquidity and asset pricing: Evidence from the Hong Kong stock market. Journal of Banking \& Finance 35(9): 2217-2230.
Lemmon, M. \& Portniaguina, E. 2006. Consumer confidence and asset prices: Some empirical evidence. Review of Financial Studies 19(4): 1500-1529.

Liao, T.L., Huang, C.J. \& Wu, C.Y. 2011. Do fund managers herd to counter investor sentiment? Journal of Business Research 64(2): 207-212.

Lintner, J. 1965. The valuation of risk assets and the selection of risky investments in stock portfolios and capital budgets. Review of Economics and Statistics 47: 13-37.

Liu, S. 2015. Investor sentiment and stock market liquidity. Journal of Behavioral Finance 16(1): 51-67.

Mahakud, J. \& Dash, S.R. 2012. Investor sentiment, risk factors and stock return: Evidence from Indian non-financial companies. Journal of Indian Business Research 4(3): 194-218.

Randall, M.R., Suk, D.Y. \& Tully, S.W. 2003. Mutual fund cash flows and stock market performance. Journal of Investing 12(1): 78-81.

Rosenberg, B., Reid, K. \& Lanstein, R. 1985. Persuasive evidence of market inefficiency. Journal of Portfolio Management 11: 9-17.

Sharpe, W. 1964. Capital asset prices: A theory of market equilibrium under conditions of risk. Journal of Finance 19: 425-442.

Stambaugh, R.F., Yu, J. \& Yuan, Y. 2012. The short of it: Investor sentiment and anomalies. Journal of Financial Economics 104(2): 288-302.

Stock, J. \& Watson, M.W. 1993. A simple estimator of cointegrating vectors in higher order integrated systems. Econometrica 61(4): 783-820.

Wang, S. \& Yu, Z. 2014. The dynamic relationship between volatility, volume and open interest in CSI 300 futures market. WSEAS Transactions on Systems 13(14): 1-11.

Yang, C. \& Li, J. 2013. Investor sentiment, information and asset pricing model. Economic Modeling 35(2013): 436-442.

Yuan, J. 2012. Human capital and asset pricing. Available at http://ssrn.com/abstract=1995532, 0-37.

Chandana Gunathilaka (corresponding author)

Department of Finance

Faculty of Management Studies and Commerce

University of Sri Jayewardenepura

10250 Nugegoda, SRI LANKA.

E-Mail: chandana@sjp.ac.lk

Mohamad Jais

Department of Accounting and Finance

Faculty of Economics and Business

University Malaysia Sarawak

94300 Kota Samarahan, Sarawak, MALAYSIA.

E-Mail: jmohamad@unimas.my 